\title{
Counternarratives: Troubling Majoritarian Certainty
}

\author{
Karin S. Hendricks \\ Boston University, Massachusetts (USA)
}

Narratives featuring majoritarian (e.g., White, male, middle/upper class, and/or heterosexual) protagonists are so prevalent in U.S. society that they have become the normative reference point by which some members of society may view and label others. They may, therefore, implicitly consider those who do not fit the majoritarian mold as somehow inferior or deficient. Counternarratives challenge majoritarian biases by normalizing the experiences of minoritized persons and inviting their stories to rupture the dominant narrative. In this article, I engage the concept of counternarratives by relating my encounter with a historical narrative that differed from the majoritarian one I had been taught. I then describe how counternarratives can take a reader on a journey through time, sociality, and place to evoke a sense of connection with a non-majoritarian protagonist and awaken the possibility for seeing the world anew. The article continues with descriptions of counternarrative texts and their potentials, first from literature and contemporary autobiography and then from within music education.

Keywords: Counternarrative, curriculum, majoritarian narratives, minoritized persons, music education, narrative

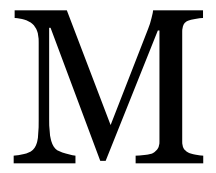

r. Harrison was an affable man, mild-tempered and easygoing in some respects. Yet, he presented lessons from our 7 th grade Utah history textbook with such precision and honor that it seemed to me-a young and impressionable child in a conservative town-as if he were teaching us the word of God. With his wavy, gray-golden hair and porcelain-looking skin, he appeared to me, in fact, to be an angel. I listened intently and with awe to the stories he told, occasionally wondering if he were somehow old enough to have experienced these historic events himself.

I worked diligently in Mr. Harrison's Utah history class, memorizing county names and recalling the experiences of trappers who settled the region. We learned about the tribulations and persistence of the Latter-day Saint pioneers, whom we called Mormons, ${ }^{1}$ including their complex relationship with Native Americans, whom we called Indians-and whom we were also taught to view historically as

(C) Karin S. Hendricks. The content of this article is the sole responsibility of the author. The ACT Journal and the Mayday Group are not liable for any legal actions that may arise involving the article's content, including, but not limited to, copyright infringement. 
savages but as present-day friends. ${ }^{2}$ Much of the history we learned centered around 19th-century religious settlers, which makes it difficult now to separate what I learned in 7th grade Utah history class from what I learned in Sunday School. The narrative was similar: one of European-American pioneers displaying industry, ingenuity, and overcoming trials to develop and prosper in a "new" land.

Some thirty years later, I came across a news article about Japanese American internment camps in World War II, something about which I previously knew nothing. I read with utter shock about how the United States government incarcerated 120,000 Japanese U.S. immigrants and citizens who were perceived to be a national threat after the bombing of Pearl Harbor. ${ }^{3}$ My shock turned to horror when I read the list of states that housed these camps, finding Utah among them.

My mind raced back to 7 th grade, to Mr. Harrison, to our Utah history textbook. Had I perhaps once learned-and then somehow forgotten-about this act of domestic terrorism that occurred just a few decades before I entered that history class? Was it mentioned merely in a sidebar of the textbook and therefore glossed over by our teacher in favor of other topics? Had it not seemed as important to Mr. Harrison as stories of pioneers praying for relief from crickets eating their crops? Or was it not as memorable an event to me as singing about Native American children leaving their homes to join our community and get a White education?4

I do not remember whether I had learned about these Japanese American internment camps as a child, but I am confident that they did not receive much emphasis either in the curriculum or in my history classrooms. Unlike best-selling author Tara Westover (2018)-who grew up just an hour's drive from my Utah home in a much more fundamentalist Latter-day Saint setting-I had learned as a child about the horrors of the Jewish holocaust under the German Nazi regime. However, the imprisonment of Japanese Americans in my state was scarcely spoken of, if at all. Instead, the history of my people had been presented as a narrative of innocence, a narrative of heroism. 5

\section{Counternarratives}

Counternarratives can play an important role in revealing stories of structural violence and oppression that majoritarian history has overlooked, misrepresented, oversimplified, and/or erased. According to Solórzano and Yosso (2002), White, male, heterosexual privilege so permeates master narratives in society that it is assumed to be the norm: 
Because "majoritarian" stories generate from a legacy of racial privilege, they are stories in which racial privilege seems "natural." ... [A] majoritarian story is one that privileges Whites, men, the middle and/or upper class, and heterosexuals by naming these social locations as natural or normative points of reference. ... Using "standard formulae," majoritarian methods purport to be neutral and objective yet implicitly make assumptions according to negative stereotypes. (28-29)

When such majoritarian models are presumed, an inherently flawed perception follows that minoritized ${ }^{6}$ individuals are somehow biologically deficient or otherwise inferior to those whose stories have been privileged.

Counternarratives, on the other hand, serve to challenge majoritarian biases by normalizing the experiences of minoritized persons and, in turn, invite other stories to rupture the dominant narrative. Counternarratives often evoke perspective-taking by using personal, third-person, or composite stories (Solórzano and Yosso 2002). Stories can make previously unknown or distant "others" seem familiar and relatable, potentially eliciting empathic connections ${ }^{7}$ that might lead to questioning, wondering, dialogue, authentic allyship, and collaborative action toward social change (Hendricks 2018a).

Storytelling is a natural part of African American, Latinx, and Native American cultures (Solórzano and Yosso 2002). ${ }^{8}$ It is not surprising, therefore, that narrative inquiry has become recognized as a viable research approach as academic societies have awakened, albeit slowly, to issues of justice and equity. Furthermore, advancements in technology and social media have provided momentum to the sharing of counternarratives. They open multiple platforms and opportunities for the dissemination of stories beyond those shared by mainstream broadcasting. 9

Storytelling was also embraced by my culture of origin as a means of teaching and preserving its history and faith. Counternarratives, however, were not-and with each new and different telling of history I eventually encountered, I faced a "troubling" of my sense of "certainty" (Barrett and Stauffer 2009) that not only put the story I had been told into question but also unsettled everything in life that was even tangentially related to that story. As Robillard (2019) explains,

Though we talk rather unproblematically about the story of our lives, there is always more than one, but never at one time. Narratives replace one another. Narratives disrupt one another. Narratives trouble one another. And narratives collapse. And just as a building collapse affects the structures surrounding it, so too does a narrative collapse affect the structures surrounding it. (xi-xii).

Allowing these counternarratives to evoke wonderings within me-or not-became a choice with a critical threshold, in that doing so could potentially unravel every 
meaning, experience, and aspect of my identity that had been carefully constructed from birth.

Counternarratives are at once both troubling and therapeutic. They draw readers less familiar with the protagonist's life experiences into another time and place, compelling them to reconsider and reimagine the human experience and sociality that exist there. They invite the reader to contemplate experiences in the past, present, and/or future from a fresh vantage point, to ask questions such as "What if?" or "How can this be?" They can evoke a sense of connection with the protagonistwho is possibly a different protagonist in the story than the reader initially assumed-and summon the reader, once they have opened to a new variation of socalled "reality," to engage differently with the world around and within them.

In the next sections, I summarize examples of counternarratives, first from literature and autobiography and then from within music education more specifically. Each counternarrative reflects a protagonist's journey through a figurative threedimensional space (i.e., time/temporality, personal/social interactions, and place) that is reflective of narrative (Clandinin and Connelly 2000). Furthermore, each example demonstrates attributes of counternarrative in that each has a non-majoritarian protagonist. Each counternarrative establishes a new point of reference from which the reader may view the world differently than the majoritarian narrative, begin a process of personal questioning, and possibly open up to new narratives.

\section{Counternarrative Texts}

In his book Counternarratives, African American writer John Keene (2015) blends political fiction with narrative experimentation (e.g., a collage of newspaper clippings, maps, and song lyrics, with authorial interruption) to "queer"1o White mainstream narratives. In so doing, he presents counternarratives that question practices of colonialism and highlights the exploitation of people of color along the path of so-called progress (see McElroy 2015). In a scathing critique of the propaganda used to aggrandize the supremacy of one culture over another, Keene inserts these words into the mouth of a dictator: "I can write the story of reality however I see fit. At any time" (Keene 2015, as cited in McElroy 2015, 683). ${ }^{11}$

In the book's second section, titled "Encounternarratives," Keene spins stories of commonly cited figures of color from literature and art on their heads, offering a different and nuanced perspective of these figures whose previous, White representations had been oversimplified and restricted. Here, formerly iconic figures of 
minoritized persons-including Jim from The Adventures of Huckleberry Finn, vaudeville's Bob Cole, and Miss La La, a trapeze artist painted by Degas-are given their own voices, an opportunity to tell their own stories and "exceed every limit placed upon [them] unless [they] place it there" (Keene 2015, as cited in McElroy 2015, 682). Through these counterstories, Keene liberates the figures by re-envisioning their role as protagonists, allowing them to speak and act for themselves.

Counternarratives also abound in Just Mercy, an autobiographical text written by Bryan Stevenson (2014), a U.S. civil rights attorney and founder of the Equal Justice Initiative. ${ }^{12}$ Stevenson artfully weaves stories of various death row and "lifer" clients (young, poor, and/or Black) who have been unjustly condemned to death or life in prison and for whom he fought for release. By following their stories through an extension of time, space, and sociality, Stevenson offers his own narrative alongside those of prisoners who-because of their isolation from societywould not otherwise be heard. Each story counters a majoritarian narrative of inherent justice in United States law, revealing instance after instance of blatant racism and corruption and calling into question ideas about equality that readers may have previously assumed to be self-evident.

By introducing each person on death row first as a fellow human-through detailed portrayals of their emotions, quirks, hopes, faith, setbacks, compassion for others, and in some cases even a penchant for singing-Stevenson creates a tangible connection between protagonists and readers who might otherwise not ever know them or have reason to interact with them. Borrowing from the words of Robillard (2019), "we find ourselves in other people's stories"-and that is the case in Just Mercy, Stevenson presents each narrative in such down-to-earth terms as to make the protagonist appear a friend, a brother, a sister, a parent, a child. As such, even in cases where the reader may remain unconvinced of a person's innocence, they may at least be persuaded that no human deserves cruel and unjust treatment. Said differently, the reader may come to recognize that there are better ways to attain justice than through a system that "harms people who harm people to show that harming people is wrong" (Butler, n.d.). ${ }^{13}$

Stevenson's counternarratives evoke an acknowledgment of the humanness, imperfections, and possibilities not only within each protagonist, but in every person. He writes: "Each of us is more than the worst thing we've ever done" (2014, 17-18). These words invite the reader to consider that each of us-as well as the society in which we live-has room for rectification. 
In her autobiography Becoming, Michelle Obama (2018) weaves narratives of her life-ornamented and enhanced with stories of her music education and music making-into counternarratives on race, gender, and class. Michelle grew up in the south side of Chicago, in a community that she viewed as normal but over time became increasingly labeled by others as "ghetto," particularly as White and wealthier families moved away to the suburbs. Growing up, Michelle never saw herself as different from any other person, nor did she view her family as different from any other family. Only as she encountered difference did she come to perceive the inequities that existed all around her.

Michelle tells the story of her first piano lessons on her Aunt Robbie's wornout piano, with keys that "had a subtle unevenness of color and shape, places where bits of the ivory had broken off over time, leaving them looking like a set of bad teeth" (9). Young Michelle was able to find middle C as her "anchoring point" (9) because that key was missing a chip the size of her fingernail. Michelle shared the story of her struggles with her teacher-aunt, who insisted that she follow along lesson by lesson and piece by piece, although Michelle wanted to jump ahead in the book. Michelle counters the mainstream music education narrative by attributing her actual musical development less to her formal lessons and more to listening to other students' lessons through the floorboards of her family's apartment above the piano studio.

The story of Michelle's musical development becomes a counternarrative that challenges mainstream narratives of race and class. Michelle describes her awakening to inequity in society at large and the field of classical music specifically, when she performed in her first piano recital in a "grand stone building on Michigan Avenue, right near where the Chicago Symphony Orchestra played" (13). Despite her diligent practice and preparation, Michelle became paralyzed when she sat down at the piano to perform. As she looked at the keys, she encountered a tangible representation of the systemic injustices against low-income individuals and people of color in the classical music industry ${ }^{14}-\mathrm{a}$ difference that seemed to counter her sense of everything, musical and otherwise:

And yet there was a problem, one I discovered in the split second it took to lift my little fingers to the keys. I was sitting at a perfect piano, it turned out, with its surfaces carefully dusted, its internal wires precisely tuned, its eighty-eight keys laid out in a flawless ribbon of black and white. The issue was that I wasn't used to flawless. In fact, I've never once in my life encountered it. ... The only instrument I'd ever played was [Aunt Robbie's] less-than-perfect upright, with its honky-tonk patchwork of yellow keys and its conveniently chipped middle C. To 
me that's what a piano was-the same way my neighborhood was my neighborhood, my dad was my dad, my life was my life. It was all I knew.

Now, suddenly, I was aware of people watching me from their chairs as I stared hard at the high gloss of the piano keys, finding nothing there but sameness. I had no clue where to place my hands. With a tight throat and chugging heart, I looked out to the audience, trying not to telegraph my panic, searching for the safe harbor of my mother's face. Instead, I spotted a figure rising from the front row and slowly levitating in my direction. It was Robbie. We had brawled plenty by then, to the point where I viewed her a little bit like an enemy. But here in my moment of comeuppance, she arrived at my shoulder almost like an angel. Maybe she understood my shock. Maybe she knew that the disparities of the world just quietly showed themselves to me for the first time. It's possible she needed simply to hurry things up. Either way, without a word, Robbie gently laid one finger on middle $\mathrm{C}$ so that I would know where to start. Then, turning back with the smallest smile of encouragement, she left me to play my song. (16)

Throughout her life, Michelle engaged in music as a means of connecting with others as well as connecting with her own identity. Her life narrative extends from her early years in the south side of Chicago, where she enjoyed listening to jazz and Motown records at her grandfather's house, to her later life when the greatest performers in the world visited her new home-the White House-so frequently that her daughters took for granted the unique experience of having Paul McCartney downstairs for a visit. One such meaningful visit occurred toward the end of the Obamas' second term, when Broadway musical Hamilton creator Lin-Manuel Miranda performed at the White House for a second time.

Although Hamilton tells a story of White United States history that is already pervasive in textbooks, Miranda's "America then, as told by America now" approach (BBC News 2017) has the potential to awaken audiences to counternarratives of that same history by raising the profile of immigrants while also humanizing legendary White figures. Songs of love, pain, and ambition, which are presented in contemporary music styles (hip-hop, jazz, R\&B), connect emotions and vulnerabilities of historical figures to sentiments expressed by modern artists, thereby making these historical figures more relatable. Furthermore, casting actors of color as venerated White founding fathers not only counters theater's troubling history of White actors performing Black theatrical roles in debasing ways (Radano 2003) but is an intentional way to highlight the parallels of immigrants in history with immigrants today. Lin-Manuel Miranda described the approach in an interview with the BBC News:

We're gonna use every tool at our disposal to eliminate the distance between a modern audience and something that happened 200 somewhat years ago... Casting it to look like the way our country looks eliminates distance... When George 
Washington is a young man of color and he's running for his life, suddenly... he's not invincible anymore.... Suddenly these are real people. (BBC News 2017, oo:38)

Michelle Obama described her experience listening to Lin-Manuel Miranda perform at the White House and how it evoked in her a recollection of the ways in which counternarratives serve to break down hegemonic narratives and celebrate the stories of minoritized people:

Hamilton touched me because it reflected the kind of history I'd lived myself. It told a story about America that allowed the diversity in. I thought about this afterward: So many of us go through life with our stories hidden, feeling ashamed or afraid when our whole truth doesn't live up to some established ideal. We grow up with messages that tell us that there's only one way to be American-that if our skin is dark or our hips are wide, if we don't experience love in a particular way, if we speak another language or come from another country, then we don't belong. That is, until someone dares to start telling that story differently. (Obama 2018, 415)

Counternarratives take courage to share, not only due to potential personal ramifications that may arise from the act of challenging those with power, but also because of the structural collapse that can accompany a narrative breakdown (Robillard 2019). Yet as suggested in Obama's quote above, without these counternarratives, majoritarian narratives continue from generation to generation, perpetuating assumptions that even shame and fear are normal. Counternarratives afford release from the grip of often feigned-yet routinely fatal-majoritarian certainty.

\section{Counternarratives in Music and Education}

Education can lead to empowerment of minoritized individuals (Freire 2007), yet those who hold power seek to control and even prevent access to knowledge that might shatter existing structures-both in general education as well as in music education (Hendricks 2018b). The U.S. educational system was initially designed to maintain the societal status quo (Bobbitt 1918, Slattery 2013); it reinforces notions of the superiority of some people over others, masked in terms such as "equal opportunity" and "success," even though educational opportunities are neither equal nor fair (Greene 1983, Hendricks 2018a). Educational structures that appear to provide equal opportunity can merely reinforce inequity when hidden curricula offer further cultural capital to those who enter the classroom already at an advantage (Apple and King 1983). 
In music education in the U.S., an extreme emphasis on competition and rankbased comparison evokes a hidden curriculum, teaching some students that they are less capable musicians if they do not achieve at the same level as those who entered the learning space with more financial and social capital to develop certain kinds of musical skills (Hendricks 2018a). Similarly, the overused, oversimplified notion of musical talent-which places some learners and teachers in a position of superiority over others-has been called "discriminatory ..., unfair, and wasteful" (Howe, Davidson, and Sloboda 1998, 399). Who determines the definition of "talent" and according to what criteria? Majoritarian notions of talent restrict opportunities for would-be music learners, who are judged to be lacking and therefore not worthy of a teacher's time, attention, or creativity.

Furthermore, Bradley (2006, 2007) and Hess (2013, 2015a, 2017, 2019) have argued that the privileging of European classical music in our school systems place not only particular genres in a position of superiority, but people from European backgrounds as well. Bradley (2007) elaborates:

Presumed moral superiority served to justify colonial conquests and their related brutalities. To view other cultures or people through the lens of moral superiority reiterates these colonialist power relations... Our music education curricula continue to validate and recognize particular (White) bodies, to give passing nods to a token few "others," and to invalidate many more through omission. The western musical canon predominates our curricula, while we continue to argue whether popular music should have a place in what our students learn, and which styles of popular music are "appropriate." Musical practices from around the world remain marginalized as curricular add-ons, if acknowledged at all. (134)

When a narrow group of music education gatekeepers defines standards and measures of "musicianship" and "quality" and then controls access to opportunities to meet those narrow criteria, individuals who might demonstrate musicianship in other ways are inherently marginalized (Robinson and Hendricks 2018, Stauffer 2017, Talbot 2018).

In the past several years, the overwhelmingly majoritarian body of music education scholars in the U.S. has increasingly welcomed ideas that counter and challenge mainstream notions of who we are, whom our field represents, and what it means to be musical. Researchers have introduced and then problematized concepts of "multiculturalism," made space for discussions of a variety of musical styles including (but not limited to) popular, rock, and hip-hop music, and tackled hegemonic issues including racism, sexism, and homophobia. Such conversations have opened the door for similar work among narrative inquirers, who aim to 
"trouble certainty" or "challenge taken-for-granted notions of the nature of life and learning in and through music" (Barrett and Stauffer 2009, 16).

One of these counternarratives in music education is “Rie's Story, Ryan's Journey" (Nichols 2013), which challenges mainstream, gendered notions of school life and shows how music can be an avenue for unique self-expression. In terms of counternarrative, this article is remarkable in three respects. First, Nichols takes the reader through various times, places, and social events in the life of Ryan/Rie, a transgender music learner, to shed light on ways that music ensembles might uniquely provide a safe community of support and self-expression for many students, yet also fail to adequately support transgender individuals. Second, by "liberat[ing] gender variance from the catchall umbrella of LGBT studies" (263), this article also challenges notions of some academic scholars that the experiences of lesbian, gay, bisexual, and transgender individuals can be subsumed into one invariant category. Third, this article was transformative for music education scholarship in that it was the first narrative, LGBTQ-related study accepted in the traditionally post-positivist Journal of Research in Music Education, thereby challenging notions of what counts as scholarship in our field.

The groundwork laid by Nichols created space for other counternarratives in music education, such as Palkki's (2016) study of three transgender students in secondary school choral programs. Palkki's research challenges taken-for-granted practices in music education such as voice part assignments, performance uniforms, ensemble tour sleeping arrangements, choral program structure, and rehearsal vocabulary. Furthermore, Palkki's research participants-each with their own unique stories-challenge assumptions that transgender individuals' experiences are monolithic. Instead, Palkki reveals how differences in time, location, and context create the uniqueness of each person's experience.

In yet another example of counternarrative scholarship, Niknafs (2017) challenges Western European and North American dominant discourse by presenting the narrative of Behzad, an Iranian musician who moved from underground rock music making to public rock music performance. Niknafs makes a case for the legitimacy of music education in Iran despite its absence in formal schooling, suggesting that

[t]he absence of music courses in public education of the young does not indicate the absence of music making and learning; rather, we must look beyond the formal discourse of music education to find salient and unexpected forms of music education. (131) 
Niknafs uses the stories of Behzad to suggest that music educators anywhere should go beyond Hess's (2015b) claim that nonwestern musics "deserve a place in the classroom" (343) and consider embracing other practices for their "distinctive, creative, collaborative, and persevered [approaches to] music making and learning" (Niknafs 2017, 131).

Talbot (2018) edited a volume of counternarratives that represent a spectrum of marginalized voices-a collection of stories intended to "rupture... the grand narrative of music education" and "thicken the texture of our music education imaginary and counter the built-up habits of coloniality... that trundle us onward toward a false teleological endpoint" (6). Owning his positionality as a "product of a [white] colonial past," (6) yet with his own stories of oppression as a gay man, Talbot invited multiple authors to make public, through their writing, stories of marginalization in music education. Chapters in the volume counter mainstream narratives of race and/or ethnicity (Lechuga and Schmidt 2018, McCall 2018, Robinson and Hendricks 2018, Thornton 2018), gender identity (Bartolome and Stanford 2018, Sears 2018) and intersectionalities of race, class, and gender (Hendricks and Dorothy 2018) and LGBTQ identity and religion (Taylor and Zeke 2018). Some chapters also challenge mainstream notions of "acceptable" instruments and/or voice parts in music programs (Bond 2018, Hendricks and Dorothy 2018, Lechuga and Schmidt 2018).

Counternarratives have become a part of music education scholarship with increased fervor, including with a recent narrative volume dedicated to "listening to voices seldom heard" (Smith and Hendricks 2020). There is still much work to be done, however. Although music learning experiences of other minoritized persons, such as students with (dis)abilities, have also been highlighted through narrative (see Blair 2009; Rathgeber 2017, 2019), scholars often still default to telling stories of marginalization through the eyes of a (privileged) researcher rather than welcoming and embracing the voices of the protagonists themselves. Welcoming and embracing the voices of the protagonists requires, at the very least, a change in the practices of majoritarian scholars, including making more concentrated efforts to read from and cite authors from under-represented groups, and collaborating with and inviting minoritized individuals into scholarly communities of practice that have heretofore been exclusive. On a broader scale, welcoming and embracing the voices of the protagonists also requires reconsidering the supremacist values that underscore majoritarian epistemologies and ontologies in the first place (Zuberi and Bonilla-Silva 2008). 
A welcome and embrace of protagonist voices requires a radical hospitality with an openness to new narratives, a willingness for old, outdated structures to collapse, and a vulnerability to discomfort and change (see Hendricks 2018a). Yet only through such openness can new ways of thinking, being, and musicking emerge. Reframing the words of Michelle Obama, the tide will turn in our conversations as each of us "dares to start telling that story differently" (2018, 415). Each emerging story, each counternarrative, disrupts mainstream music narratives in its own way and helps us to envision a field that is more equitable, empowering, and full of possibility.

\section{Return to a New Beginning}

Over three decades passed before I saw Mr. Harris again. I had moved away from the area some time earlier but came back to visit, and I caught a glimpse of him from a distance at a community event. He looked strangely odd to me, away from the formidable backdrop of his classroom. His gray-golden hair was draped over by a large, white, round hat, and his teaching uniform of crisply ironed khakis was replaced by polyester trousers that bunched up at his feet. Although he appeared fully engaged in his interactions with others, he nevertheless looked lost to me. Seeing him outside of his teaching domain offered a counter to the narrative I had held of him all those years, eclipsing the image of a strong and angelic authority figure with the presence of a simple, unassuming neighbor who lived down the street.

My awareness of my own history had crossed a critical threshold by this point, and I would never view Mr. Harris the same again. Equipped with new information about the fallible facts I learned (and didn't learn) about Utah history in his class, I saw this man now as very much human-no longer omniscient, no longer perfect. I viewed him as a fellow learner, just like me. Perhaps he, too, had simply taught us what someone had taught him. If so, I had no right to judge him harshly but rather to use my new awareness to change the narrative for those I teach. ${ }^{15}$

\section{Conclusion}

In one sense the movement to embrace counternarratives appears profound; however, in another sense, we in the field of music education might wonder, "What is taking us so long?" Could it be that we fear the structural and/or ideological collapse that often accompanies encounters with previously unknown musics and 
musical counternarratives? Indeed, the traditional musical training in our field is often attended by a pedagogy of perfectionism and control, which by its essence can render change, spontaneity, and the unknown as terrifying and even deadly (McGrath, Hendricks, and Smith 2016; Smith, Hendricks, and Mesner 2018). In contrast, counternarratives, which "trouble certainty" (Clandinin 2009), invite multiple tellings of multiple stories, without a need for any sense of resolution. Can we be that open?

Perhaps one antidote to a fear of change might be found in counternarratives, which-similar to the examples above-can help to make alternative viewpoints appear closer and more viable. Or perhaps counternarratives might, one by one and each in their own way, help us become more accustomed to mystery and improvisation. Perhaps, as Clandinin (2009) suggested, "the only certainty that might remain is the certainty of uncertainty" (203). And perhaps uncertaintywith its kaleidoscopic range of possibility-need not be so troubling after all.

\section{Acknowledgment}

The author acknowledges the support of Kính T. Vũ and Jessandra Kono in preparing this manuscript.

\section{About the Author}

Karin S. Hendricks is Associate Professor and Chair of Music Education at Boston University, and recently completed a term as Director of Undergraduate Studies for the School of Music. She has served as an instrumental music clinician, adjudicator, and workshop presenter throughout the United States and abroad. Dr. Hendricks is a past secretary of the American String Teachers Association and currently serves on the Editorial Committees of String Research Journal and Journal of Research in Music Education. She publishes regularly in leading research journals and edited books and makes a particular effort to present research findings to music teachers in meaningful and approachable ways. She was the 2018 recipient of the American String Teachers Association “Emerging String Researcher” Award. Before moving to the collegiate level, Karin enjoyed a successful public school orchestra career for 13 years, where she received local, state, and national awards for her teaching. Dr. Hendricks has published six books, including Compassionate Music Teaching. 


\section{References}

Apple, Michael, and Nancy King. 1983. What do schools teach? In The hidden curriculum and moral education, edited by Henry Giroux and David Purpel, 82-99. Berkeley, CA: McCutchan Publishing.

Barrett, Margaret S., and Sandra L. Stauffer, eds. 2009. Narrative inquiry in music education: Troubling certainty. New York, NY: Springer Netherlands.

Bartolome, Sarah J., and Melanie E. Stanford. 2018. "Can't I sing with the girls?”: A transgender music educator's journey. In Marginalized voices in music education, edited by Brent C. Talbot, 114-36. New York, NY: Routledge.

BBC News. 2017. Hamilton creator: It's a "story of America then told by America now.” (December 23). https://www.bbc.com/news/av/entertainment-arts42464676/hamilton-creator-it-s-a-story-of-america-then-told-by-americanow

Blair, Deborah V. 2009. Nurturing music learners in Mrs. Miller's "family room": A secondary classroom for students with special needs. Research Studies in Music Education 31 (1): 20-36.

Bobbitt, Franklin, 1918. The curriculum. Boston, MA: Houghton Mifflin.

Bradley, Deborah. 2006. Music education, multiculturalism and anti-racism: Can we talk. Action, Criticism, and Theory for Music Education 5 (2): 2-30. http://act.maydaygroup.org/articles/Bradley5_2.pdf

Bradley, Deborah. 2007. The sounds of silence: Talking race in music education. Action, Criticism, and Theory for Music Education 6 (4): 132-62. http://act.maydaygroup.org/articles/Bradley6_4.pdf

Bond, Vanessa L. 2018. Like putting a circle with a square: A male alto's choral journey. In Marginalized voices in music education, edited by Brent C. Talbot, 137-52. New York, NY: Routledge.

Brooks, Joanna. 2020. Mormonism and White supremacy: American religion and the problem of racial innocence. Oxford University Press.

Butler, Shakti. n.d. Healing justice. WorldTrust: Social Impact through Film and Dialogue. https://world-trust.org/product/healing-justice/

Campbell, Patricia Shehan. 2002. Music education in a time of cultural transformation. Music Educators Journal 89 (1): 27-32. https://doi.org/10.2307/3399881 
Clandinin, D. Jean, and F. Michael Connelly. 2000. Narrative inquiry: Experience and story in qualitative research. San Francisco, CA: Jossey-Bass Publishers.

Clandinin, D. Jean. 2009. Troubling certainty: Narrative possibilities for music education. In Narrative inquiry in music education: Troubling certainty, edited by Margaret S. Barrett and Sandra L. Stauffer, 201-210. New York, NY: Springer Netherlands.

Cohen, Mary L. 2012. Harmony within the walls: Perceptions of worthiness and competence in a community prison choir. International Journal of Music Education 30 (1): 46-56. https://doi.org/10.1177/0255761411431394

Freire, Paulo. 2007. Pedagogy of the oppressed, 3oth anniversary edition. New York, NY: Continuum.

Garrett, Matthew. 2016. Making Lamanites: Mormons, Native Americans, and the Indian student placement program, 1947-2000. Salt Lake City, UT: University of Utah Press.

Greene, Maxine. 1983. Introduction. In The hidden curriculum and moral education, edited by Henry Giroux and David Purpel, 1-5. Berkeley, CA: McCutchan Publishing.

Hartman, Saidiya V. 1997. Scenes of subjection: Terror, slavery, and self-making in 19th-century America. New York, NY: Oxford University Press.

Hendricks, Karin S., 2018a. Compassionate music teaching. Lanham, MD: Rowman and Littlefield.

Hendricks, Karin S., 2018b. Gaga spirituality. In Queering freedom: Music, identity and spirituality, edited by Karin S. Hendricks and June Boyce-Tillman, 243-26o. Oxford, U.K.: Peter Lang.

Hendricks, Karin. S., and Dorothy. 2018. Negotiating communities of practice in music education: Dorothy's narrative. In Marginalized voices in music education, edited by Brent C. Talbot, 65-79. New York, NY: Routledge.

Hendricks, Karin S., and June Boyce-Tillman, eds. 2018. Queering freedom: Music, identity and spirituality. Oxford, U.K.: Peter Lang.

Hendricks, Karin S. 2021. Authentic connection in music education: A chiastic essay. In Authentic connection: Music, spirituality, and wellbeing, edited by Karin S. Hendricks and June Boyce-Tillman, 237-53. Oxford, U.K.: Peter Lang. 
Hess, Juliet. 2013. Performing tolerance and curriculum: The politics of self-congratulation, identity formation, and pedagogy in world music education. Philosophy of Music Education Review 21 (1): 66-91. https://muse.jhu.edu/article/509095/pdf

Hess, Juliet. 2015a. Upping the "anti-": The value of an anti-racist theoretical framework in music education. Action, Criticism, and Theory for Music Education 14 (1): 66-92. http://act.maydaygroup.org/articles/Hess14_1.pdf

Hess, Juliet. 2015b. Decolonizing music education: Moving beyond tokenism. International Journal of Music Education 33: 336-47.

https://doi.org/10.1177/0255761415581283

Hess, Juliet. 2017. Equity and music education: Euphemisms, terminal naivety, and whiteness. Action, Criticism \& Theory for Music Education 16 (3): 1547. http://act.maydaygroup.org/articles/Hess16_3.pdf

Hess, Juliet. 2019. Music education for social change: Constructing an activist music education. New York, NY: Routledge.

Howe, Michael J. A., Jane W. Davidson, and John A. Sloboda. 1998. Innate talents: Reality or myth? Behavioral and Brain Sciences 21 (3): 399-407. doi: 10.1017/So140525X9800123X

Keene, John. 2015. Counternarratives. New York, NY: New Directions Publishing.

Lechuga, Carlos Castañeda, and Margaret Schmidt. 2018. Cultural straddling: The double life of a mariachi music education major. In Marginalized voices in music education, edited by Brent C. Talbot, 80-98. New York, NY: Routledge.

Lindsey, Alex, Eden King, Michelle Hebl, and Noah Levine. 2015. The impact of method, motivation, and empathy on diversity training effectiveness. Journal of Business and Psychology 30 (3): 605-617. doi: 10.1007/s10869-0149384-3

McCall, Joyce M. 2018. Speak no evil: Talking race as an African American in music education. In Marginalized voices in music education, edited by Brent C. Talbot, 13-27. New York, NY: Routledge.

McCarty, Teresa L. (2002). A place to be Navajo: Rough Rock and the struggle for self-determination in Indigenous schooling. New York, NY: Routledge.

McElroy, Alex. 2015. Review: Counternarratives by John Keene. The Georgia Review 69 (4): 680-83. https://www.jstor.org/stable/44077682. 
McGrath, Casey, Karin S. Hendricks, and Tawnya D. Smith. 2016. Performance anxiety strategies. Lanham, MD: Rowman and Littlefield.

Nichols, Jeananne. 2013. Rie's story, Ryan's journey: Music in the life of a transgender student. Journal of Research in Music Education 61 (3): 26279 .

Niknafs, Nasim. 2017. The story of a man without lips: Representational politics in Iranian music education. Bulletin of the Council for Research in Music Education 210-211: 119-35.

Obama, Michelle. 2018. Becoming. New York, NY: Random House.

Palkki, Joshua. 2016. "My voice speaks for itself": The experiences of three transgender students in secondary school choral programs. PhD diss, Michigan State University.

Pavlik, Steve. 1992. Of saints and Lamanites: An analysis of Navajo Mormonism. Wicazo Sa Review 8 (1): 21-30. https://www.jstor.org/stable/pdf/140936o.pdf

Radano, Ronald M. 2003. Lying up a nation: Race and Black music. Chicago, IL: The University of Chicago Press.

Rathgeber, Jesse. 2017. A place in the band: Negotiating barriers to inclusion in a rock band setting. In The Routledge research companion to popular music education, edited by Gareth Dylan Smith, Zack Moir, Matt Brennan, Shara Rambarran, and Phil Kirkman, 369-81. New York, NY: Routledge.

Rathgeber, Jesse. 2019. Troubling disability: Experiences of disability in, through, and around music. PhD diss., Arizona State University.

Razack, Sherene H. 2007. Stealing the pain of others: Reflections on Canadian humanitarian responses. Review of Education, Pedagogy, and Cultural Studies 29 (4): 375-94. https://doi.org/10.1080/10714410701454198

Riggs, Lynette. 2008. The Church of Jesus Christ of Latter-day Saints' Indian student placement service: A history. PhD diss., Utah State University.

Robillard, Amy E. 2019. We find ourselves in other people's stories: On narrative collapse and a lifetime search for story. New York, NY: Routledge.

Robinson, Deejay, and Karin S. Hendricks. 2018. Black keys on a white piano: A Negro narrative of double-consciousness in American music education. In Marginalized voices in music education, edited by Brent C. Talbot, 28-45. New York, NY: Routledge. 
Sears, Colleen A. 2018. "Put your big girl panties on!”: A female band director's career in a culture of masculinity. In Marginalized voices in music education, edited by Brent C. Talbot, 99-113. New York, NY: Routledge.

Slattery, Patrick. 2013. Curriculum Development in the postmodern era: Teaching and learning in an age of accountability. New York, NY: Routledge.

Smith, Tawnya D., and Karin S. Hendricks. 2020. Narratives and reflections in music education: Listening to voices seldom heard. Cham, Switzerland: Springer.

Smith, Tawnya D., and Karin S. Hendricks. 2021. Diversity, inclusion, and access. In The Oxford handbook of musical performance, edited by Gary E. McPherson, in press. Oxford University Press.

Smith, Tawnya D., Karin S. Hendricks, and Kerr Mesner. 2018. Throbbing dissonance: An ethnodrama on identity experienced through cello wolf tone theory. In Queering freedom: Music, identity, and spirituality, edited by Karin S. Hendricks and June Boyce-Tillman, 305-321. Oxford, U.K.: Peter Lang.

Solórzano, Daniel G., and Yosso, Tara J. 2002. Critical race methodology: Counter-storytelling as an analytical framework for education research. Qualitative inquiry 8 (1): 23-44.

Stauffer, Sandra L. 2017. Whose imaginings? Whose future? Keynote talk for the Society for Music Teacher Education 2017 Conference, Minneapolis, MN. https://www.academia.edu/34543397/Whose_Imaginings_Whose_Futures

Stevenson, Bryan. 2014. Just mercy: A story of justice and redemption. New York, NY: Random House.

Talbot, Brent C. Introduction. In Marginalized voices in music education, edited by Brent C. Talbot, 1-12. New York, NY: Routledge.

Talbot, Brent C., ed. 2018. Marginalized voices in music education. New York, NY: Routledge.

Taylor, Don, and Zeke. 2018. Zeke's story: Intersections of faith, vocation, and LGBTQ identity in the South. In Marginalized voices in music education, edited by Brent C. Talbot, 153-75. New York, NY: Routledge.

Thornton, Darrin. 2018. Why just me (or few others) in music education: An autoethnographic point of departure. In Marginalized voices in music education, edited by Brent C. Talbot, 46-64. New York, NY: Routledge. 
Vaugeois, Lise. 2013. Colonization and the institutionalization of hierarchies of the human through music education: Studies in the education of feeling. $\mathrm{PhD}$ dissertation, University of Toronto.

Westover, Tara. 2018. Educated: A memoir. New York, NY: Random House.

Zuberi, Tukufu, and Eduardo Bonilla-Silva, eds. 2008. White logic, white methods: Racism and methodology. Lanham, MD: Rowman \& Littlefield.

\section{Notes}

${ }^{1}$ The Church of Jesus Christ of Latter-day Saints is perhaps best known by the nickname "Mormon"-a name that the church has either embraced or rejected at different times in its history, depending on different leaders and corresponding philosophies. At the time of this writing, the church is rejecting the nickname. See https://www.nbcnews.com/news/us-news/don-t-use-mormon-or-lds-churchname-president-says-n901491

${ }^{2}$ When I was in grade school there was an initiative for White, Latter-day Saint families to adopt Navajo children from nearby reservations, presumably to provide a "better" life and raise them with Christian principles (see Riggs 2008). It was part of a missionary effort begun in 1947 that led to an estimated 20\% of Navajos having joined the church by the 1980 os (Pavlik 1992). Church leaders celebrated the initiative by suggesting that the skin of Navajo children in the program was literally becoming "white and delightsome" (Garrett 2016). The church stopped this program in the mid-1990s. Notably, this program took place approximately 100 years after the infamous Bosque Redondo displacement, where United States officials attempted the practice of ethnic cleansing of Navajo and Mescalero Apache people; see http://nmhistoricsites.org/bosque-redondo. See footnote 4.

3 See http://time.com/5314955/separation-families-japanese-internmentcamps/ and https://www.smithsonianmag.com/history/injustice-japanese-americans-internment-camps-resonates-strongly-180961422/

4 "Go My Son" was presented to us in elementary school as a song about an "Indian chief" encouraging his son to leave the tribe and get an education to "raise up" the rest of the tribe. The song has a rising and falling pentatonic tune, with lyrics such as "go and climb the ladder" and "go and take a lofty view." As I discovered later through an Internet search, the song was written by Brigham Young University students Arlienne Nofchissey (Navajo) and Carnes Burnes (Ute) and was featured in countless university and public-school stage productions in the area. We learned actions to go along with the music and words, which I now question regarding their authenticity and origin. Ironically, although my generation was taught the song in "celebration" of the "Indian Student Placement Program" (where Navajo children were taken out of their homes to live with white families; see footnote 2), the song 
is now featured on gomyson.com, an online platform for teaching and preserving the Navajo language.

5 Religious historian Joanna Brooks (2020) has described how the narrative of White innocence-as propagated by American Christianity-has played a role in entrenching White supremacy in society at large, in that its proponents can absolve themselves of any wrongdoing and subsequent need to change beliefs, perceptions, and/or personal behavior. The narrative of White innocence is related to the concept of "terminal naivety" (Vaugeois 2013), which Hess (2017) has defined as "political disinterestedness" (19) such as has helped to maintain structures of White supremacy in music education.

${ }^{6}$ I use the term "minoritized" instead of "minority" in this article, given that the latter term is often statistically inaccurate, whereas the preferred term emphasizes the power relations whereby certain groups are marginalized and/or oppressed (McCarty 2002, xv).

7 Empathy, as defined in Compassionate Music Teaching (Hendricks 2018a), is not to be confused with sympathy or pity, which would infer an unequal or dominant relationship and serve to maintain harmful power dynamics. Instead, I refer to empathy as the act of Einfühlung, "feeling into" (affective empathy); or perspective-taking (cognitive empathy), which are neutral experiences in their own right and could inform any variety of actions or inactions. There is a possibility (although not an assurance) that counternarratives might elicit a kind of empathy among individuals-no matter whether privileged or minoritized themselves-who have previously taken majoritarian narratives for granted. As explained elsewhere in this article, the act of relating to a counternarrative's protagonist can lead to further questioning and the unraveling of interrelated narratives. Empathic connections may potentially lead to action, given evidence that perspective-taking leads to allyship better than education alone (Lindsey et al. 2015). On the other hand, it is important to recognize "the slipperiness of empathy" (Hartman 1997, 18), where experiencing the pain of another might lead a person to focus on their own discomfort rather than the imperative toward action. In such cases, one might "steal the pain of others" as a means of justifying their own morality and maintaining a sense of superiority (Razack 2007; see also Brooks 2020 and footnote 5 above). As I have argued elsewhere, inauthentic empathy germinates not only through segregation and abstraction, but also by a "misguided sense of piety or religious innocence" that can lead one to "shift the blame elsewhere and ... perpetuate a cycle of disconnect from reality" (Hendricks 2021, 241). Authentic empathy, however, requires letting go of superiority or "hero" narratives and exercising compassion not as a badge of morality, but as a way of recognizing common humanity and the need for collaborative action (Hendricks 2018, 2021).

8 While working on this article I had the opportunity to visit a historic Native American village in New Mexico. While there, I heard a Pueblo woman describe

Hendricks, Karin S. 2021. Counternarratives: Troubling majoritarian certainty. Action, Criticism, and Theory for Music Education 20 (4): 58-78. https://doi.org/10.22176/act20.4.58 
stories as having a heartbeat: The more stories are told, the more alive they become; the less they are told, the more likely those stories are to die.

9 One example of broad dissemination via technology is the recent murder of George Floyd at the hands of Minneapolis police officer Derek Chauvin. Although police brutality toward people of color is not at all a new phenomenon, this particular instance gained international attention and led to massive protests, in part because of the ease by which multiple videos of the brutal killing (including Floyd's pleas for his mother and his own life breath) were made public instantaneously.

10 "Queering" here refers to the deconstruction of dualisms and culturally assumed labels that serve to privilege or uphold certain traditions or viewpoints as superior to, or more desirable than, their alleged opposites. It invites a radical liberation from binaries and imposed labelling that, much like a counternarrative, evokes new perspectives and possibilities. For examples of queering in music discourse, see Hendricks and Boyce-Tillman, 2018.

${ }^{11}$ This quote highlights the ability of authoritarian leaders (whether dictators, religious leaders, etc.) to change existing narratives at any time to preserve their power. These new narratives are often immediately embraced by faithful followers-even when they contradict previous versions of reality-not only because of the dictator's threat of oppression over anyone in the system who might disagree, but in some cases because of the followers' fear of structural collapse if they were to lose faith in their leader (see Robillard 2019; Westover 2018).

${ }^{12}$ https://eji.org

${ }^{13}$ I express appreciation to Mary Cohen for introducing me to Shakti Butler's video Healing Justice, which illuminates many of the problems that the American prison system causes for marginalized communities. Mary's own work with the Oakdale Prison Choir serves as a counternarrative-producing experience for its members, who are either prison inmates or members of the larger community (see Cohen 2012).

${ }^{14}$ See Smith and Hendricks (2021) for further detail about the history of injustice in this industry.

${ }^{15}$ Recently, one of my former students posted on social media that she was frustrated by her lack of education regarding the Juneteenth holiday. Although I cannot speak for her other teachers, she was correct that I had never taught her about it, because I had never been taught about it myself. Seeing her post while working on this article offered an unexpected counter to my own narrative, an opportunity to forgive, and the motivation to keep learning. 